\title{
4
}

\section{Comparative Foreign Relations Law between Center and Periphery}

\author{
Liberal and Postcolonial Perspectives
}

Michael Riegner

\section{TAKING GLOBAL COMPARISON SERIOUSLY}

Nine months before his death in a US-backed military coup, Chilean President Salvador Allende delivered an acclaimed speech to the UN General Assembly that must have been electrifying. As he concluded, the packed Assembly hall erupted into enthusiastic applause and shouts of 'Viva Allende!'. Allende's 1972 speech marked an important rallying cry in the Third World's mobilization against a global economic order dominated by industrialized countries and Western multinational corporations. ${ }^{2}$ Defending the nationalization of US-owned copper and telecommunications firms, Allende declared that '[o] ur economy could no longer tolerate the state of subordination implied in the concentration of more than 80 per cent of its exports in the hands of a small group of large, foreign companies.' ${ }^{3}$ He mounted a spirited attack against multinational corporations' economic 'aggression' and 'imperialist intervention' into Chile's political affairs. Conscious that he was expressing a grievance shared by many developing countries, Allende concluded: 'We are witnessing a pitched battle between the great transnational corporations and sovereign States ... In a word, the entire political structure of the world is being undermined.'4 Allende's apprehension was no leftist

1 Robert Alden, 'Mr. Allende follows outline of speech', New York Times, December 5, 1972, www.nytimes.com/1972/12/05/archives/allende-at-un-charges-assault-by-us-interests-chilean-pr esident.html (all websites last accessed September 30, 2020).

2 On the historical context, see Jochen von Bernstorff and Philipp Dann, The Battle for International Law: North-South Perspectives on the Decolonization Era (Oxford: Oxford University Press, 2019).

3 Salvador Allende, 'Address delivered at 2096th Plenary Meeting, 4 December 1972, New York', Official Records of the United Nations General Assembly (1972), para. 9.

4 Allende, Official Records UN General Assembly, para. 59. 
paranoia: in 1973, he was ousted and died in a coup that was supported by the CIA and US-corporate interests and ushered in Augusto Pinochet's military dictatorship. ${ }^{5}$ Beyond this extreme case, empirical research attests not only to the economic leverage of multinationals over many developing countries but also to the eminently political role transnational corporations have played in many Southern nations. $^{6}$

Allende's speech is typically seen as a milestone towards a New International Economic Order in international law. ${ }^{7}$ Beyond that, however, the Allende story also offers a different perspective on foreign relations law: one that is shaped by the postcolonial contexts and historical experiences of countries at the periphery of the global political economy. This perspective thus differs from conceptions of foreign relations law that developed in liberal democracies at the center of geopolitical gravity. If foreign relations law is to take global comparison seriously, it needs to take into account this peripheral perspective. Doing so not only pluralizes comparative foreign relations law and thus makes it more representative. It might also help us understand contemporary transformations of foreign relations law in Western liberal democracies, as these legal orders become less centric and more peripheral in a new multipolar geopolitical context.

Extant literature in foreign relations law is shaped by liberal perspectives from the center. As a field of study, foreign relations law is commonly thought to have originated in the peculiar context of the United States, shaped as much by its federal and presidential system as by its geopolitical centrality and dominance. ${ }^{8}$

5 On US involvement in the coup see Tanya Harmer, Allende's Chile and the Inter-American Cold War (Chapel Hill: University of North Carolina Press, 2011); Anthony Sampson, The Sovereign State of ITT (New York: Stein Day, 1973); United States Senate, 'First Session, Volume 7: Covert Action', Hearings Before the Select Committee to Study Governmental Operations with Respect to Intelligence Activities, Ninety Fourth Congress, 1975, available at www.intelligence.senate.gov/resources/intelligence-related-commissions, p. 15 f., 158 f.

6 Bastiaan van Apeldoorn and Nana de Graaf, 'The Corporation in Political Science', in Grietje Baars and Andre Spicer (eds.), The Corporation: A Critical, Multi-Disciplinary Handbook (Cambridge: Cambridge University Press, 2017), pp. 134-59; Lorraine Eden and Evan H. Potter, Multinationals in the Global Political Economy (London: Palgrave Macmillan UK, 1993); Theodore H. Moran, Multinational Corporations and the Politics of Dependence (Princeton: Princeton University Press, 1974); Raymond Vernon, Sovereignty at Bay: The Multinational Spread of U.S. Enterprises (London: Longman, 1971).

7 Cf. Sundhya Pahuja and Anna Saunders, 'Rival Worlds and the Place of the Corporation in International Law', in Jochen von Bernstorff and Philipp Dann (eds.), The Battle for International Law: South-North Perspectives on in the Decolonization Eera (Oxford: Oxford University Press, 2019), pp. 141-74.

8 Curtis A. Bradley, 'Foreign Relations Law as a Field of Study' (2017) 111 AJIL Unbound 316 at 319. But see on the nineteenth-century idea of 'Äußeres Staatesrecht' in Germany Helmut Philipp Aust, "The Democratic Challenge to Foreign Relations Law in Transatlantic Perspective', in David Dyzenhaus, Jacco Bomhoff and Thomas Poole (eds.), The Double- 
Most recent treatments of foreign relations law focus on one single legal order or compare a small number of 'Western' liberal democracies, typically the US, the UK, Germany or the European Union. ${ }^{9}$ This state of affairs carries the risk, as Helmut Aust has put it, "to fall into the trap of a self-referential, liberal, and Western mindset which takes discussions in a few jurisdictions of the "Global North" as being representative of the broader global picture. ${ }^{10}$

This chapter does not address this problem by adding new legal material from the Global South to the existing comparative framework. Rather, the aim is to uncover and pluralize the theoretical assumptions and epistemic foundations of the existing comparative framework. This endeavor can draw on a longstanding critique of the epistemic limitations of traditional comparative law and on the emerging literature on a constitutionalism of the Global South. ${ }^{11}$ Two desiderata emerge from this literature, one methodological and one epistemic: methodologically, a global comparison requires not only a more representative case selection but also increased attention to the heterogenous historical, political-economic and legal-cultural contexts that shape the meaning and function of foreign relations law in both North and South. ${ }^{12}$ Foreign relations law is not simply a national

Facing Constitution: Legal Externalities and the Reshaping of the Constitutional Order (Cambridge: Cambridge University Press, 2020), pp. 345-75.

9 Campbell McLachlan, Foreign Relations Law (Cambridge: Cambridge University Press, 2014); Robert Schütze, Foreign Affairs and the EU Constitution: Selected Essays (Cambridge: Cambridge University Press, 2016); Curtis A. Bradley and Jack L. Goldsmith, Foreign Relations Law: Cases and Materials (New York: Wolters Kluwer, 2017); Helmut Philipp Aust, 'Foreign Affairs', Max Planck Encyclopedia of Comparative Constitutional Law (2017), http://oxcon.ouplaw.com/home/MPEC COL; Thomas Kleinlein, "TTIP and the Challenges of Investor-State-Arbitration: An Exercise in Comparative Foreign Relations Law', in Anna-Bettina Kaiser, Niels Petersen and Johannes Saurer (eds.), The U.S. Supreme Court and Contemporary Constitutional Law: The Obama Era and Its Legacy (Baden-Baden: Nomos, 2018), pp. 211-28; Curtis A. Bradley (ed.), The Oxford Handbook of Comparative Foreign Relations Law (New York: Oxford University Press, 2019) (which does contain chapters on India, South Africa, China and Commonwealth African Countries). Conversely, standard comparative law treaties tend not to consider 'foreign relations' as a self-standing field for comparison, see e.g. Michel Rosenfeld and András Sajó (eds.), The Oxford Handbook of Comparative Constitutional Law (Oxford: Oxford University Press, 2013); Susanna Dorsen et al., Comparative Constitutionalism: Cases and Materials (St. Paul: West Academic Publishing, 2016).

10 Aust, 'Foreign Affairs', para. 6.

${ }^{11}$ Philipp Dann, Michael Riegner and Maxim Bönnemann (eds.), The Global South and Comparative Constitutional Law (Oxford: Oxford University Press, 2020); Zoran Oklopcic, 'The South of Western Constitutionalism: A Map Ahead of a Journey' (2016) 37 Third World Quarterly 2080; Daniel Bonilla Maldonado, Constitutionalism of the Global South (Cambridge: Cambridge University Press, 2013); Günter Frankenberg, 'Critical Comparisons: Rethinking Comparative Law' (1985) 26 Harvard International Law Joumal 411.

12 On contextual comparison see generally Günter Frankenberg, 'Comparing Constitutions: Ideas, Ideals, and Ideology - Toward a Layered Narrative' (2006) 4 ICON 439. On the combination of contextual and functionalist methods see already M. Riegner, 'Access to Information As a Human Right and Constitutional Guarantee. A Comparative Perspective’ 
reflection of universal international principles but remains deeply embedded in different varieties of constitutionalism, including non-liberal variants. ${ }^{13}$ Epistemically, the challenge is thus to go beyond mere addition and to question, provincialize and pluralize the theoretical concepts and epistemic categories that prestructure the comparative inquiry. ${ }^{14}$ Comparatists need to make explicit the underlying assumptions that define and structure foreign relations law as a field of study and to empirically test, rather than implicitly presuppose, their universal validity beyond Western liberal democracy.

This chapter pursues this approach in two steps. Section II contrasts two idealtypical perspectives on foreign relations law, a liberal one from the center and a postcolonial one from the periphery. These perspectives differ in their approach to epistemic structure, normative functions and legal subjects of foreign relations law. These differences come into sharp relief in the legal treatment of transnational corporations, whose sociolegal reality questions categorical distinctions between international and national, political and economic, state and individual. For the purposes of this chapter, I take Salvador Allende's speech to be illustrative of this particular peripheral perspective, which was however widely shared at the time by many Third World nations and whose legacy lives on in contemporary varieties of constitutionalism in the Global South. Section III goes further and argues that the peripheral perspective is not exclusive to an essentialized 'South' but has increasing resonance and heuristic value in the 'North', as it highlights contemporary transformations in liberal-democratic foreign relations law. Again, these transformations can be studied through the changing attitudes towards transnational corporations, which represent one possible avenue for future

(2017) 50 VRÜ / Law and Politics in Asia, Africa and Latin America 332 at 353 ff. On case selection see Ran Hirschl, "The Question of Case Selection in Comparative Constitutional Law' (2005) 53 American Journal of Comparative Law 125; Cheryl Saunders, 'Towards a Global Constitutional Gene Pool' (2009) 4 National Taiwan University Law Review, 1.

13 See generally Mark Tushnet, 'Editorial: Varieties of Constitutionalism' (2016) 14 ICON 1; Oscar V. Vieira, Uprenda Baxi and Frans Viljoen (eds.), Transformative Constitutionalism: Comparing the Apex Courts of Brazil, India and South Africa (Pretoria: Pretoria University Law Press, 2013); Michael W. Dowdle and Michael A.Wilkinson (eds.), Constitutionalism beyond Liberalism (Cambridge: Cambridge University Press, 2017); Helena A. García and Günter Frankenberg (eds.), Authoritarian Constitutionalism: Comparative Analysis and Critique (Cheltenham: Edward Elgar Publishing, 2019).

14 Oklopcic, 'The South of Western Constitutionalism'; Florian Hoffmann, 'Knowledge Production in Comparative Constitutional Law' in Philipp Dann, Michael Riegner and Maxim Bönnemann (eds.), The Global South and Comparative Constitutional Law (Oxford: Oxford University Press, 2020) pp. 41-66; Ina Kerner, 'Beyond Eurocentrism: Trajectories Towards a Renewed Political and Social Theory' (2018) 44 Philosophy \& Social Criticism 550. On provincializing, see generally Dipesh Chakrabarty, Provincializing Europe: Postcolonial Thought and Historical Difference (New Delhi: Oxford University Press, 2000). 
comparative research. Section IV concludes with some thoughts on the possibilities and limits of drawing lessons from historical and global comparisons.

\section{TWO PERSPECTIVES ON FOREIGN RELATIONS LAW: FROM CENTRE TO PERIPHERY}

This following section develops and contrasts two perspectives on foreign relations law, the liberal one from the center (subsection A), and the postcolonial one from the periphery (subsection B). These should be prefaced with three caveats: firstly, they are ideal-typical perspectives that do not neatly map onto the actual law of any particular state, nor are they representative of the entire 'Global North' or 'South'. Rather, the aim is to contrast different contexts, ideological formations and epistemic structures and to offer alternative ways of thinking about foreign relations law. Secondly, ideological and epistemic difference does not hamper 'comparability' but has heuristic value precisely in uncovering implicit assumptions and teaching us as much about the self than the other. Thirdly, contrasting the two perspectives does not, at this stage, imply a normative judgment on which is the 'better' view. Normatively speaking, the peripheral view does not require abandoning questions about, and a commitment to, democracy, separation of powers and individual rights typically asked in liberal foreign relations law; but it commands a pluralized and contextualized understanding of these concepts.

\section{A Liberal Foreign Relations Law from the Center}

If recent handbook and encyclopedia articles are representative of the existing literature, then foreign relations law is defined, in its core, as the domestic legal norms that govern the participation of state organs in diplomatic relations and international lawmaking; beyond that, it arguably includes the domestic effects of these international activities, especially international law, and individual rights protection in internationalized situations. ${ }^{15}$ The main research questions and normative concerns pertain to the operation of separation of powers, democracy and individual rights at the interface between the international and domestic sphere.

15 Curtis A. Bradley, 'What Is Foreign Relations Law?', in Curtis A. Bradley (ed.), The Oxford Handbook of Comparative Foreign Relations Law (New York: Oxford University Press, 2019), p. 3; Aust, 'Foreign Affairs', para. 8; McLachlan, Foreign Relations Law, 7 ff. 
These definitions and concerns are informed by a liberal perspective from the center of geopolitical gravity. ${ }^{16}$ This perspective is shaped by specific contexts: the legal-cultural context is liberal-democratic constitutionalism. The dominant ideological influence is liberalism as it evolved in Europe and North America since the seventeenth century, embodied by intellectual forerunners like Locke, Blackstone, Mann and others. ${ }^{17}$ Historically, it is shaped by an experience of statehood in which the nation state preexists international law and is located at the center of an imperially structured global order. Economically, these states have been capital exporting market economies, either of the liberal or coordinated variety of capitalism. ${ }^{18}$

The liberal, centric perspective is defined by particular ideas about the structure, function and subjects of foreign relations law: (1) its epistemic structure is based on a binary distinction between international and national that is rigidly applied to the political sphere, but not necessarily to the economic sphere; (2) its normative function is to protect internal and external, political sovereignty by allocating powers to different branches and levels of government; (3) its agency structure is based on two paradigmatic legal subjects: the state and the individual, who has a dual existence as a national citoyen and transnational bourgeois. In short, the liberal foreign relations law is focused primarily on relations among states and on political constitutionalism.

This perspective implies particular conceptions of sovereignty, democracy, separation of powers and rights that are embedded in the broader Western constitutional tradition. The epistemic structure of liberal foreign relations law rests on an understanding of sovereignty that establishes a binary distinction between international and national, external and internal, outside and inside. In this distinction, the national preexists, and autonomously determines its relationship to, the international. Foreign relations law is conceived as the domestic interface where this determination is made. Globalization is perceived as an external force that the state opens itself up to in choosing between 'open' or 'closed' statehood. Importantly, the distinction between international and national is applied rigidly to the political sphere but not to

16 I use 'liberal' to designate a particular constitutional tradition and political philosophy. This usage does not correspond to the meaning of 'liberal' as a position in partisan politics, where it can designate 'progressive' or 'left' in the US, or rather the opposite in Europe. Obviously, even within the meaning used here, there are different shades and traditions. On varieties of liberalism, see generally Michael Freeden, Liberalism: A Very Short Introduction (Oxford: Oxford University Press, 2015), 37 ff.; Duncan Bell, 'What Is Liberalism?' (2014) 42 Political Theory 682.

17 McLachlan, Foreign Relations Law, 31 ff.; Aust, 'Foreign Affairs', para. 1.

18 Peter A. Hall and David W. Soskice (eds.), Varieties of Capitalism: The Institutional Foundations of Comparative Advantage (Oxford: Oxford University Press, 2001). 
the economic sphere. The separation of economy and politics by domestic constitutionalism is a well-known feature of nineteenth-century classical liberalism. Legally, this separation was effected by the constitutional protection of economic rights against political power - whether exercised by authoritarian executives or democratically elected legislatures. Importantly for foreign relations, as the economic sphere is separated from the state, it remains possible to imagine a 'world market' or a 'global economy', to which the liberal state opens itself by allowing for free trade and foreign investment. ${ }^{19}$ Internally as externally, its economic role thus tends to be that of a (de)regulator.

This epistemic structure prefigures the normative functions ascribed to foreign relations law. These functions derive from a specific understanding of sovereignty in the different spheres. Sovereignty governs the political sphere, where it follows a dual logic: internationally, sovereignty translates into the requirement of state consent, typically expressed by executive actors. Internally, the logic is popular sovereignty, which requires political rights, democracy and separation of powers. Foreign relations law, then, is essentially about which of the two logics governs the interface of national and international. Importantly, this dual logic does not apply in the same way to the economic sphere, which transcends the national-international binary and remains governed at least as much by the logic of individual liberty and economic rights. Indeed, as historian Quinn Slobodian has recently shown, a key feature of normative order in the twentieth century was the extension of neo- and ordoliberal principles to the international realm: the legal separation between imperium and dominium, sovereignty and property kept economic integration possible in a world of ending empires and multiplying democratic nation states. ${ }^{20}$

The epistemic structure and normative functions also determine ideas about agency and legal subjectivity. The paradigmatic actors and legal subjects of liberal foreign relations law are the state and the individual. In this binary structure, the state has authority, the individual has liberty. Individual liberty is protected by rights, which differ on the national versus international, political versus economic axes: political rights are, in principle, bounded by the state: the citoyen is a national. In contrast, economic rights extend beyond the state: the bourgeois transcends the national. This idea is most developed in the European Union: supranational free movement rights have direct effect

19 M. Fichera, 'Liberalism', Max Planck Encyclopedia of Comparative Constitutional Law (2017), https://oxcon.ouplaw.com/home/MPECCOL.

20 Quinn Slobodian, Globalists: The End of Empire and the Birth of Neoliberalism (Cambridge: Harvard University Press, 2018). 
and supremacy in domestic constitutional orders. In practice, the bourgeois is often not a human being but a legal person, typically a corporation. In liberal foreign relations law, corporations have legal subjectivity but do not constitute a separate category of actors. If they appear at all, it is under the rubric of 'informality', 'citizens or residents of other nations' or 'individuals'. ${ }^{21}$ In the binary liberal framework, corporations simply pose a problem of attribution, and they are typically attributed to the sphere of the private individual: corporations are expressions of economic liberty and creatures of private law, a legal fiction designed to facilitate the accumulation of capital and its transnational mobility.

The result of this overall framework is neatly summed up by political theorist Christian Volk:

What states and global governance institutions do is political, and political is equated with significant, important, primary; economic, in contrast, is equated with secondary, private, profane. Hidden behind this, of course, is also a normative program, namely that of the (democratic) self-determination of society through the state. But there is a high price to be paid for this program: The political power of private-economic actors remains invisible. ${ }^{22}$

\section{B A Postcolonial Perspective from the Periphery}

If foreign relations law emerged as an autonomous field of study in liberal democracies like the US, the UK and Germany, this does not mean that other states have no law governing foreign relations. ${ }^{23}$ This observation implies, on the one hand, that a global comparison of foreign relations law is in principle possible. On the other hand, it carries the risk of transplanting legal concepts and epistemic categories that developed in a liberal, centric frame of reference into different contexts. As comparative law teaches us, both the meaning and the social function of legal concepts can vary with context. In the context of liberal democracies, foreign relations law may have the function of allocating jurisdiction and external powers to protect political self-determination and individual liberty. ${ }^{24}$ But we cannot simply assume that this is true in different

${ }^{21}$ Aust, 'Foreign Affairs', para. 35; Bradley, 'What Is Foreign Relations Law?', p. 3; McLachlan, Foreign Relations Law, p. 27.

22 Christian Volk, 'The Problem of Sovereignty in Globalized Times' (2019) Law, Culture and the Humanities, Online First 1 at 17.

23 Bradley, 'What Is Foreign Relations Law?', p. 8 f.

24 Campbell McLachlan, 'Five Conceptions of the Function of Foreign Relations Law', in Curtis A. Bradley (ed.), The Oxford Handbook of Comparative Foreign Relations Law (New York: Oxford University Press, 2019), pp. 21-44. 
contexts shaped by different varieties of constitutionalism, geopolitical positions and epistemic frameworks. ${ }^{25}$ Rather than assuming similarity, this chapter takes the different historical and political-economic context as starting point for an alternative perspective that looks at foreign relations law from the postcolonial periphery. 'Periphery' here designates a decentered position in the economic geography of contemporary capitalism, while 'postcolonial' refers to the condition shaped by the many legacies of colonial domination. ${ }^{26}$

Salvador Allende's 1972 speech can be read as manifesto of the peripheral perspective, in as much as it crystallizes formative experiences, epistemic categories and legal concepts prevalent across the Third World at the time. It captures a historical moment in which rapid decolonization gave rise to alternative political and legal imaginations in the periphery, embodied especially by the UN Declaration on Permanent Sovereignty over Natural Resources and the Declaration for the Establishment of a New International Economic Order adopted in $1974 \cdot{ }^{27}$ While these initiatives are often dismissed as inconsequential in international law, they were also an important expression of, and influence on, constitutional law within Third World countries. Within these legal orders, they found fertile ground in traditions of social and economic constitutionalism, inaugurated by the Mexican constitution of 1917 and the Weimar constitution of 1919, which both influenced constitutional traditions in the developing world. ${ }^{28}$

25 See generally Boaventura de Sousa Santos, Epistemologies of the South: Justice against Epistemicide (Boulder: Paradigm Publishers, 2014).

26 For a contemporary legal approach to economic geography, see Michael Dowdle, 'On the Regulatory Geography of Modern Capitalism: Putting "Rule of Law" in its Place', Oxford Centre for Socio-Legal Studies Discussion Series (2018), www.law.ox.ac.uk/sites/files/oxlaw/ dowdle_putting_rule_of_law_in_its_place.pdf. Classically, Immanuel Wallerstein, The Modern World System I (New York: Academic Press, 1974), p. 302: 'The periphery of a worldeconomy is that geographical sector of it wherein production is primarily of lower ranking goods'. On the concept of 'postcolonial' in comparative law, see only Philipp Dann and Felix Hanschmann, 'Post-colonial Theories and Law' (2012) 45 VRÜ / Law and Politics in Asia, Africa and Latin America 12; Judith Schacherreiter, 'Postcolonial Theory and Comparative Law: On the Methodological and Epistemological Benefits to Comparative Law through Postcolonial Theory' (2016) 49 VRÜ / Law and Politics in Asia, Africa and Latin America 291, both with further references.

27 Mohammed Bedjaoui, Towards a New International Economic Order (Paris: UNESCO, 1979); Antony Anghie, 'Legal Aspects of the New International Economic Order' (2015) 6 Humanity 145; Ingo Venzke, 'Possibilities of the Past Histories of the NIEO and the Travails of Critique' (2018) 20 Journal of the History of International Law 263.

28 Roberto Gargarella, Latin American Constitutionalism, 1810-2010: The Engine Room of the Constitution (New York: Oxford University Press, 2013), pp. 105 ff.; David Jungbluth, Die Entwicklung des deutschen Wirtschaftsverfassungsrechts: Von Weimar bis zum Investitionshilfeurteil (Wiesbaden: Springer Verlag, 2018), pp. 15 ff. 
In terms of ideological influences, the peripheral perspective popularized by Allende owed much to dependency theorists like Raul Prebisch and postcolonial thinkers like Franz Fanon, who sympathized with Marxist ideas all while rejecting many aspects of actually existing socialism. ${ }^{29}$ As for liberalism, there was and is little enthusiasm for those liberal varieties that subjected the periphery to freetrade imperialism and, later on, to crippling neoliberal structural adjustment. ${ }^{30}$ In terms of historical context, foreign relations did not begin as interstate relations but as dealings between chartered trading companies like the East India Company and local rulers. ${ }^{31}$ The experience of statehood was also quite different: for many postcolonial states, the international preceded the national; peripheral statehood was produced and defined by international law during decolonization. The state was the only form of political organization that was legally available for collective self-determination. ${ }^{32}$ For many new states, decolonization meant political independence but continued economic dependence: they depended on imports of capital and technology and on volatile exports of primary commodities, which were often foreign-owned or locked into unequal concessions agreements. In response, they experimented with industrial policies of import substitution and mixed or planned economies. ${ }^{33}$

This context gave rise to legal thinking about foreign relations that differs from the liberal-centric perspective in terms of structure, function and agency: (1) the epistemic structure is based on transnational and hybrid categories that transcend the binary opposition between national and international, political and economic; (2) the normative functions include enhancing economic selfdetermination, socioeconomic development and equality; (3) the agency structure is plural, including legal subjects ranging from state and individual to corporations, indigenous peoples and rights of nature. In short, peripheral foreign relations law is broader than the liberal one: it includes economic relations with powerful non-state actors and aspects of economic constitutionalism.

29 Matias E. Margulis, The Global Political Economy of Raúl Prebisch (Milton: Taylor and Francis, 2017); Frantz Fanon, The Wretched of the Earth (New York: Grove Press, 2004 [1961]), pp. $97 \mathrm{ff}$.

30 Andrew S. Sartori, Liberalism in Empire: An Alternative History (Berkeley: University of California Press, 2014).

${ }^{11}$ Philip J. Stern, The Company-State: Corporate Sovereignty and the Early Modern Foundations of the British Empire in India (Oxford: Oxford University Press, 2011).

32 But see on intellectual alternatives Adom Getachew, Worldmaking after Empire: The Rise and Fall of Self-Determination (Princeton: Princeton University Press, 2019).

33 Luis Eslava, 'The Developmental State: Independence, Dependency, and History of the South', in Philipp Dann and Jochen von Bernstorff (eds.), The Battle for International Law: South-North Perspectives on the Decolonization Era (Oxford: Oxford University Press, 2019), pp. 71-100; Magnus Feldmann, 'Global Varieties of Capitalism' (2019) 71 World Politics 162; Margulis, The Global Political Economy of Raúl Prebisch. 
This way of thinking about foreign relations law implies different conceptions of sovereignty, collective self-determination and rights. In terms of epistemic structure, the dichotomy of international and national has less historical and sociological plausibility. International law not only produced the peripheral state, but also pervaded it from the outset: international institutions midwifed, nurtured, socialized many of the new states; postcolonial law was 'modernized' in the image of Western law in 'law and development' efforts; land, natural resources and corporations were often foreign-owned; globalization was not external but internal to the state. ${ }^{34}$ In this situation, the category of transnationalism might be a more accurate representation of peripheral relations with the rest of the world. Similarly, the separation of the political and economic spheres had less plausibility in the periphery. In the history of colonialism, sovereignty and property had been closely entangled: colonization frequently began with land acquisition, and corporate property rights often became functionally equivalent to sovereignty. ${ }^{35}$ After the end of formal colonization, colonial hierarchies lived on in privatized property relationships. The transnational corporations symbolized this entanglement of economic and political power so vociferously denounced by Allende in this 1972 speech. This historical experience gave credit to the idea that economic relations were political, and vice versa.

These epistemic differences translated into different functions of foreign relations law. After decolonization had achieved political independence, sovereignty became closely associated with economic self-determination and development. The external and internal spheres were not differentiated by a dual logic of political sovereignty but bound together by one unitary rationality: development. Externally, peripheral sovereignty was not defined by consent to preexisting international law but conditioned on the state of development - from the mandate system to weighted voting in international financial institutions. Internally, peripheral states came into being as developmental states, whose teleology was to 'modernize' and 'catch up' with European statehood. ${ }^{36}$ Nationalizations of 'system-relevant' enterprises, as

34 Guy F. Sinclair, To Reform the World: International Organizations and the Making of Modern States (Oxford: Oxford University Press, 2017); Eslava, 'The Developmental State'.

35 Matthias Goldmann, 'Colonial Law as a Symbolic Order: Property and Sovereignty in German Southwest Africa', SSRN (2019), October 28, 2018, https://papers.ssrn.com/sol3/pap ers.cfm?abstract_id=3274198; Brenna Bhandar, Colonial Lives of Property: Law, Land, and Racial Regimes of Ownership (Durham: Duke University Press, 2018); Mieke van der Linden, 'The Neglected Colonial Root of the Fundamental Right to Property: African Natives' Property Rights in the Age of New Imperialism and in Times Thereafter' (2015) 75 Zeitschrift für ausländisches öffentliches Recht und Völkerrecht 791.

$3^{6}$ Eslava, 'The Developmental State'. 
those defended by Allende in his speech, were a means to achieve economic independence, development and substantive equality. A separation of the economic and political was neither epistemically plausible nor normatively desirable. If there was a concern with separation, then it was separation of powers in the private sphere, whereas the state needed a strong executive to confront multinational corporations. Thus, the function of the law was to realize economic sovereignty, ideals of economic democracy and a measure of economic equality.

Thirdly, peripheral agency structure is not binary but plural. The state and the individual are important but not exclusive actors. There is a category of legal subjects that occupies an intermediary space between the individual and the state. Legal subjectivity and constitutional rights are granted to corporations, other collective actors like trade unions and indigenous peoples, and most recently even to nature itself. ${ }^{37}$ Corporations are not only economic but political entities, and they have their own transnational reality independent from the private law of any particular state. As Allende put it in another speech in 1972: corporations 'have become a supranational force that is threatening to get completely out of control ... They have their objectives, their own policies with regard to trade, shipping, international affairs and economic integration, their own view of things, their own activity, their own world. ${ }^{3} 8$

This 'supranational' status was ensured by a variety of legal techniques: the internationalization of concession agreements and contracts between states and investors, which insulated them from the domestic law of the host state; the submission of investor-state disputes to international arbitration, which removed them from the jurisdiction of domestic courts of the host state, as became evident with the rise of such disputes in the 1990s; and finally the extraterritorial enforcement of arbitral awards in all major jurisdictions, which placed host countries at the mercy of foreign courts, often those in the investor's home state. ${ }^{39}$ Against this quasi-supranational status, Allende asserted home state jurisdiction and the supremacy of home state law:

37 Paola Villavicencio Calzadilla and Luis J. Kotzé, 'Living in Harmony with Nature?: A Critical Appraisal of the Rights of Mother Earth in Bolivia' (2018) 7 Transnational Environmental Law 397; Elena Blanco and Anna Grear, 'Personhood, Jurisdiction and Injustice: Law, Colonialities and the Global Order' (2019) 10 Journal of Human Rights and the Environment 86.

$3^{8}$ Salvador Allende, 'Address delivered at the Inaugural Ceremony, 13 April 1972, Santiago, Chile', Proceedings of the United Nations Conference on Trade and Development (1973), 349, paras. 58, 6o.

39 Muthucumaraswamy Sornarajah, 'The Battle Continued: Rebuilding Empire through Internationalization of State Contracts', in Philipp Dann and Jochen von Bernstorff (eds.), 
The Chilean Constitution provides that nationalization disputes should be resolved by a tribunal which, like all tribunals in my country, has complete independence and sovereignty in the adoption of decisions ... we shall continue with undiminished determination to maintain that only the Chilean courts are competent to pass judgment in any dispute concerning the nationalization of our basic resources. For Chile, this is not merely an important problem of juridical interpretation; it is a question of sovereignty.

Indeed, it is far more than this - it is a question of survival. $4^{\circ}$

It is this question of survival that defined the foreign relations law in much of the worlds' periphery.

Allende's reference to the Chilean constitution provides one concrete example of how the peripheral perspective translates into positive constitutional law: in July 1971, a constitutional amendment had enabled the nationalization of the copper industry by declaring that the state 'has absolute, exclusive, inalienable and imprescriptible domain over all mines' a provision still in force at the time of writing (article 19 XXIV of the constitution of 1980). ${ }^{4^{1}}$ While this chapter is not the place for a systematic comparison of positive legal provisions across time and space, some further examples might still serve to illustrate the theoretical points made above.

In this regard, provisions on public ownership of natural resources like the ones in Chile are not an isolated example but a recurring theme of a foreign relations law that rejects the liberal dichotomy of economy and politics, property and sovereignty. Many postcolonial constitutions introduced similar provisions that allowed for the nationalization of assets of transnational corporations and that constituted the domestic equivalent of international law claims to permanent sovereignty over natural resources. ${ }^{42}$ Several examples thus stem from the heyday of the New International Economic Order: the

The Battle for International Law: South-North Perspectives on the Decolonization Era (Oxford: Oxford University Press, 2019), pp. 175-97.

4० Salvador Allende, 'Address delivered at 2096th Plenary Meeting, 4 December 1972, New York', para. $47,52$.

41 Ley 17450 of 16.7.1971, available at www.leychile.cl/Navegar?idNorma=29026\&idParte=\&id Version=1971-07-16; on the context see Wolf Radmann, 'Staatliche Beteiligungs- und Verstaatlichungsvereinbarungen mit den ausländischen Kupferbergbaugesellschaften in Chile und Sambia' (1971) 4 VRÜ / Law and Politics in Asia, Africa and Latin America 301 at 317 .

42 On permanent sovereignty over natural resources in international law see Nico Schrijver, Sovereignty over Natural Resources: Balancing Rights and Duties (Cambridge: Cambridge University Press, 2008); Sundhya Pahuja, Decolonising International Law: Development, Economic Growth and the Politics of Universality (Cambridge: Cambridge University Press, 2011), pp. $95 \mathrm{ff}$. 
independence constitution of Angola of 1975, for instance, declared all natural resources, including oil and minerals, property of the state (article 11, today article 16 of the constitution of 2010). Iran, known to international lawyers for protracted arbitration over the nationalization of its oil industry, provides in its constitution of 1979 that 'mineral deposits' shall be at the disposal of the Islamic government (article 45), excludes foreigners from mineral extraction concessions (article 81) and prohibits agreements resulting in foreign control over natural resources (article 153). The current Constitution of Kenya (2010) not only declares all minerals and mineral oils to be 'public land' (article 61 I lit. f), but also requires parliamentary approval for the grant of natural resource concessions (article 71). ${ }^{43}$

Other examples come from an older constitutional tradition in Latin America, which is often associated with the Calvo doctrine in international law. Domestically, the Mexican constitution of 1917 vested ownership of natural resources like petroleum in the nation (article 27), and the Brazilian constitution of 1967 stipulated a public monopoly for petroleum exploration and exploitation (article 162, today articles 176 and 177). ${ }^{44}$ Latin America also offers other examples beyond public ownership. Constitutional land rights of indigenous peoples, for instance, illustrate the plural agency structure of a postcolonial foreign relations law. In particular, the requirement of free, prior and informed consultation is recognized in constitutional law, either by the constitutional text like in Bolivia (article 30.II.15, 352, 403) or by constitutional case law like in Colombia. ${ }^{45}$ In practice, this requirement can lead to quasi-diplomatic negotiations between indigenous representatives and private transnational corporations in which the state plays merely a moderating role, if at all. ${ }^{6}$

43 On these provisions see Petra Gümplová, 'Popular Sovereignty over Natural Resources: A Critical Reappraisal of Leif Wenar's Blood Oil from the Perspective of International Law and Justice' (2018) 7 Global Constitutionalism 173; Schrijver, Sovereignty over Natural Resources, p. 263.

44 On the significance of these provisions, see John Gledhill, “The People’s Oil”: Nationalism, Globalization, and the Possibility of another Country in Brazil, Mexico, and Venezuela' (2008) 52 Focaal 57. On the related approach to property, see Manuel Garcia-Mora, 'The Calvo Clause in Latin American Constitutions and International Law' (1950) 33 Marquette L. Rev. 205.

45 From the Colombian case law, see inter alia Constitutional Court, cases SU-039/97; C-169/ 2001. More generally, Rachel Sieder, 'Indigenous Peoples' Rights and Law in Latin America' in Cesár Rodríguez Garavito (ed.), Law and Society in Latin America: A New Map (Abingdon: Routledge, 2015), pp. 143-57.

$4^{6}$ Jessika Eichler, 'Indigenous Peoples' Land Rights in the Bolivian Lowlands' (2016) 5 International Human Rights L. Rev. 119; César Rodríguez Garavito and Carlos Baquero Díaz, 'The Right to Free, Prior, and Informed Consultation in Colombia: Advances and Setbacks' (2018), www.ohchr.org/Documents/Issues/IPeoples/EMRIP/FPIC/GaravitoAndDi az.pdf. 
While these examples all illustrate elements of the peripheral perspective in positive law, they still evince a considerable diversity in terms of actual practice and wider constitutional context, which ranges from mixedeconomy constitutional democracies like Brazil to authoritarian systems like Iran. This diversity suggests that constitutionalism in the Global South is too heterogeneous to attribute one uniform peripheral perspective to its foreign relations law. If one is intent on finding a measure of convergence, an intraregional perspective might be more promising. One example for such a regional approach to foreign relations law is regional integration in Latin America, which is still influenced by peripheral experiences. The model of regional integration espoused by Latin American states has recently been labelled as a multi-level exercise in 'transformative constitutionalism'47 a variety of constitutionalism that is often conceived as a 'Southern' alternative to 'Northern' liberal constitutionalism. ${ }^{4}$

This model of open statehood differs from its European counterpart in its differential constitutional openness for human rights and economic integration. ${ }^{49}$ Human rights norms and case law from the Inter-American system enjoy a privileged constitutional status in contemporary foreign relations law in Latin America. This status is based on explicit opening clauses such as article 93 of the Constitution of Colombia and on incorporation doctrines like the block of constitutionality' and 'conventionality control'. . $^{\circ}$ These doctrines accord international civil, political and social rights a status that is comparable to EU-type direct effect and, in some jurisdictions, supremacy. In contrast, regional economic integration and international economic law do not enjoy a similarly

47 Armin von Bogdandy et al. (eds.), Transformative Constitutionalism in Latin America: The Emergence of a New Ius Commune (Oxford: Oxford University Press, 2017). For a discussion, see Michael Riegner, 'Transformativer Konstitutionalismus und offene Staatlichkeit im regionalen Verfassungsvergleich mit Lateinamerika' (2019) 67 Jahrbuch des öffentlichen Rechts der Gegenwart 265.

$4^{8}$ The concept has multiple origins but is typically associated with Karl Klare, 'Legal Culture and Transformative Constitutionalism', (1998) 14 South African Journal on Human Rights 146. See also Vieira, Baxi and Viljoen, Transformative Constitutionalism. For a discussion of the claim of Southern particularism, see Michaela Hailbronner, 'Transformative Constitutionalism: Not Only in the Global South' (2017) 65 American Journal of Comparative Law 527 .

49 Armin von Bogdandy, 'Ius Constitutionale Commune en América Latina: Observations on Transformative Constitutionalism', in Armin von Bogdandy et. al. (eds.), Transformative Constitutionalism in Latin America: The Emergence of a New Ius Commune (Oxford: Oxford University Press, 2017), pp. 27-48.

5० Mariela M. Antoniazzi and Pablo S. Alessandri, 'Inter-Americanization: Its Legal Bases and Political Impact', in Armin von Bogdandy et al. (eds.), Transformative Constitutionalism in Latin America: The Emergence of a New Ius Commune (Oxford: Oxford University Press, 2017), pp. 255-76 with further references. 
privileged constitutional status..$^{51}$ And while the Inter-American human rights acquis protects collective rights of social groups like indigenous peoples, ${ }^{52}$ it does not recognize rights of legal persons like corporations - unlike the European Court of Human Rights and the Court of Justice of the EU. ${ }^{53}$ Overall, this model of regional integration thus focuses on openness towards supranational guarantees for democratic and social constitutionalism, whereas economic constitutionalism remains located at the national level - quite the reverse of the European model.

\section{CONTEMPORARY TRENDS: IS FOREIGN RELATIONS LAW BECOMING MORE PERIPHERAL?}

The following section begins by sketching the changing context which gives the peripheral perspective increasing resonance across the North-South-divide (subsection A). Against this background, it seeks to illustrate the heuristic value of peripheral research perspectives, which shed light on three contemporary trends in foreign relations law (subsection B): the rebalancing of the relationship between property and sovereignty in investment law; the hybridization of foreign relations through state-owned enterprises; and attempts at limiting private corporate power, or quasi-sovereignty, in debates about business and human rights.

\section{A Changing Context: Peripheral Echoes in the Center}

In June 2018, the US White House published a report denouncing China's 'economic aggression', warning that 'Beijing's ultimate goal is for domestic companies to replace foreign companies as designers and manufacturers of key technology and products first at home, then abroad ... [C]orporate

${ }^{51}$ Liliana Lizarazo Rodríguez and Philippe de Lombaerde, 'Regional Economic Integration and the Reality of Strong National Constitutional Powers in South America: A Comparative Analysis' (2017) 11 International Constitutional Law Journal 365. On the relationship of Latin American transformative constitutionalism to international economic law, see Armin von Bogdandy et al., El constitucionalismo transformador en América Latina y el derecho económico internacional: De la tensión al diálogo (México: UNAM/MPIL, 2018).

52 Ximena Soley, 'The Transformative Dimension of Inter-American Jurisprudence', in Armin von Bogdandy et al. (eds.), Transformative Constitutionalism in Latin America: The Emergence of a New Ius Commune (Oxford: Oxford University Press, 2017), pp. 337-55.

53 Cf. Anna Grear, Redirecting Human Rights: Facing the Challenge of Corporate Legal Humanity (Houndmills, Basingstoke: Palgrave Macmillan, 2010); Thomas Kleinlein, 'Die juristische Person des Privatrechts in der Rechtsprechung des EGMR' (2017) 65 Jahrbuch des öffentlichen Rechts der Gegenwart 85. 
governance has become a tool to advance China's strategic goals, rather than simply, as is the custom of international rules, to advance the profitmaximizing goals of the enterprise'. ${ }^{54}$ Soon, this political stance had legal consequences: the Chinese telecommunications company Huawei was banned by Congress from sensitive public procurement, and the US administration is pushing for Huawei's exclusion from ${ }_{5} \mathrm{G}$ networks in the US and Western allies. ${ }^{55}$ As other governments were pondering such a move, the UK House of Commons published a report addressing the role of social media companies in 'Disinformation and "fake news": It found that 'malicious forces use Facebook to ... influence elections and democratic processes - much of which Facebook, and other social media companies, are either unable or unwilling to prevent. We need to apply widely-accepted democratic principles to ensure their application in the digital age. ... The big tech companies must not be allowed to expand exponentially, without constraint or proper regulatory oversight. ${ }^{156}$

These statements echo some themes familiar from Allende's speech: the hybrid nature of corporations between the political and the economic; their impact on democracy; and their role in foreign relations. These echoes do not necessarily imply that Euro-America is evolving towards the South, as prominent anthropologists claim. ${ }^{57}$ They do show, however, that peripheral ideas on foreign relations law are not exclusive to an essentialized 'South' but have increasing resonance in the changing context of foreign relations law in the 'North'. This context is marked by intensifying contestations of liberal democracy, of economic liberalism and of liberal internationalism..$^{8}$ The geopolitical context is increasingly shaped by emerging powers like China

54 White House Office of Trade and Manufacturing Policy, How China's Economic Aggression Threatens the Technologies and Intellectual Property of the United States and the World (2018), available at www.whitehouse.gov/wp-content/uploads/2018/o6/FINAL-China-TechnologyReport-6.18.18-PDF.pdf, $1,11$.

55 National Defense Authorization Act of 2018, Pub. L. No. 115-91, 131 Stat. 1283 (2017), s. 1656; Paul Mozur and Austin Ramzy, 'Huawei Sues US Government over what it Calls an Unfair Ban', New York Times, March 6, 2019, www.nytimes.com/2019/03/o6/business/huawei-united -states-trade-lawsuit.html.

56 'Disinformation and "fake news": Final Report' (2019 HC 1791), p. 5.

57 Jean Comaroff and John. L. Comaroff, Theory from the South: Or, how Euro-America is Evolving toward Africa (Boulder: Paradigm, 2012).

${ }_{58}$ Mark A. Graber, Sanford Levinson and Mark V. Tushnet (eds.), Constitutional Democracy in Crisis? (New York: Oxford University Press, 2018); Manuel Castells, Rupture: The Crisis of Liberal Democracy (Newark: Polity Press, 2018); Thomas Piketty, Capital in the Twenty-First Century (Cambridge: Harvard University Press, 2014); Wolfgang Streeck, Buying Time: The Delayed Crisis of Democratic Capitalism (London: Verso, 2014); Dani Rodrik, 'Populism and the Economics of Globalization' (2018) 1 Journal of International Business Policy 12. 
and by the incremental evolution of Western liberal democracies from capital exporters to capital importers, from norm shapers to norm takers. ${ }^{59}$

In this new multipolar context, international law is increasingly 'hitting home', and foreign relations law is evolving in response. ${ }^{60}$ A peripheral perspective brings these transformations of foreign relations law into focus. Its main heuristic value in contemporary times is the recognition that in an economically interdependent and multipolar world, foreign relations law is not limited to political relations but requires attention to the materiality of global relations, to interferences between different varieties of economic constitutionalism, and to the interdependence of economic and political constitutionalism. Again, this general point can be illustrated by legal attitudes towards transnational corporations. ${ }^{61}$

\section{B Peripheral Perspectives on Contemporary Trends in Foreign Relations Law}

\section{Rebalancing Sovereignty and Property in Foreign Investment Law}

A first trend is the rebalancing of the relationship between sovereignty and property in the area of investment law. Standard narratives portray international investment law as an evolution from diplomatic protection of private property by sovereign states to a depoliticization and privatization of property disputes between investors and states. ${ }^{62}$ Consequently, investment law has not been in the focus of liberal foreign relations law. However, host countries in the Global South have been experiencing for some time that international investment protection and arbitration can interfere with domestic constitutional principles of democracy, rule of

59 William Burke-White, 'Power Shifts in International Law: Structural Realignment and Substantive Pluralism’ (2015) 56 Harvard Journal of International Law 1; Oliver Stuenkel, PostWestern World: How Emerging Powers are Remaking Global Order (Cambridge: Polity Press, 2016).

6o Aust, 'The Democratic Challenge to Foreign Relations Law in Transatlantic Perspective', at 351 .

61 On renewed criticisms of corporate power, see generally Florian Wettstein, Multinational Corporations and Global Justice: The Human Rights Obligations of a Quasi-Governmental Institution (Stanford: Stanford Business Books, 2009); Baars and Spicer, The Corporation: A Critical, Multi-Disciplinary Handbook; Adam Winkler, We the Corporations: How American Businesses Won their Civil Rights (New York: Liveright, 2018).

62 A. Kulick, 'Narrating Narratives of International Investment Law: History and Epistemic Forces', in Stephan W. Schill, Christian. J. Tams and Rainer Hofmann (eds.), International Investment Law and History (Cheltenham: Edward Elgar Publishing, 2018), pp. 41-69. For the reverse trend, see now Rodrigo Polanco Lazo, The Return of the Home State to Investor-State Disputes: Bringing Back Diplomatic Protection? (Cambridge: Cambridge University Press, 2019). 
law and human rights. ${ }^{63}$ This peripheral experience has eventually hit home with recent controversies about TTIP, CETA and TPP in Europe and North America. ${ }^{64}$ This is leading to re-evaluation, reform and sometimes repudiation of bilateral investment treaties and arbitration agreements across the North-South divide. ${ }^{65}$ These reform efforts seek to recalibrate the relationship between property and sovereignty, a process which can arguably draw important lessons from peripheral legal experiences, concepts and arguments. As a recent observer put it: developed countries have learned to start worrying and love the Calvo doctrine. ${ }^{66}$

If one takes peripheral perspectives on the structure, function and subjects of foreign relations law seriously, then at least three issues lend themselves to further investigation. The first concerns the legal relations between foreign investors and the host states, be they contractual or hierarchical. If these legal relations are part of foreign relations, then the question of who decides about the admission of foreign investment, in what procedure and under what conditions is a critical question for foreign relations law. For jurisdictions like Germany, such criticality, or Wesentlichkeit, may have doctrinal consequences under prevailing doctrines of separation of powers and democracy: public relations with foreign investors may need to be increasingly subjected to parliamentary legislation instead of executive regulation. ${ }^{67}$

The second issue is jurisdiction. If investor-state relations are part of foreign relations, then the question of how foreign relations law allocates investment

63 Pahuja, Decolonising International Law, 95 ff; Muthucumaraswamy Sornarajah, Resistance and Change in the International Law on Foreign Investment (Cambridge: Cambridge University Press, 2015); Yannick Radi (ed.), Research Handbook on Human Rights and Investment (Cheltenham: Edward Elgar Publishing, 2018).

64 Kleinlein, 'TTIP and the Challenges of Investor-State-Arbitration'; Peter-Tobias Stoll, Till P. Holterhus and Henner Gött, Investitionsschutz und Verfassung (Tübingen: Mohr Siebeck, 2017); Rhea T. Hoffmann, Divergenz und Transformation: Verfassungstheoretische Untersuchung des Eigentumsschutzes in der demokratischen Eigentumsverfassung und im Investitionsschutzregime (Baden-Baden: Nomos, 2019); Ntina Tzouvala, "The Academic Debate about Mega-Regionals and International Lawyers: Legalism as Critique?' (2018) 6 London Review of International Law 189.

65 Steffen Hindelang and Markus Krajewski (eds.), Shifting Paradigms in International Investment Law: More balanced, less isolated, increasingly diversified (Oxford: Oxford University Press, 2016); Prabhash Ranjan, India and Bilateral Investment Treaties: Refusal, Acceptance, Backlash (New Delhi: Oxford University Press India, 2019).

66 See generally Rodrigo Polanco Lazo, 'The No of Tokyo Revisited: Or How Developed Countries Learned to Start Worrying and Love the Calvo Doctrine' (2015) 30 ICSID Review 172. On potential lessons from the South, see Fabio Morosini and Michelle R. Sanchez Badin (eds.), Reconceptualizing International Investment Law from the Global South (New York: Cambridge University Press, 2017).

67 See generally on the constitutional implications of investment protection treaties, Stoll, Holterhus and Gött, Investitionsschutz und Verfassung. 
disputes among host state courts, arbitral tribunals and third-country judiciaries is a key question. ${ }^{68}$ From a peripheral perspective, the enforcement of arbitral awards against host states in third-country jurisdictions is a key interface between state and non-state legal systems. Behind seemingly technical questions regarding standards of review for annulment or non-execution of awards on the basis of public policy lurk fundamental questions of transnational legal pluralism and protection of foreign property, sovereignty, democracy and rule of law. ${ }^{6}$

A third issue is the domestic effect of international investment law and arbitral awards in host countries. If a domestic constitutional order contains opening clauses for international law, do these apply to international investment treaties? And what is the domestic effect of arbitral awards? This latter question was less relevant as long as tribunals awarded monetary compensation that would be paid voluntarily or be enforced against state assets abroad. But recent awards also adopt in-kind remedies. In a 2018 award in the Chevron v. Ecuador saga, the Permanent Court of Arbitration ordered Ecuador 'to remove the status of enforceability' from domestic court judgments and 'to preclude any of the [plaintiffs] from enforcing' them. ${ }^{70}$ These judgments had required Chevron to pay damages to local residents and had been confirmed by the Ecuadorian constitutional court. Implementing such an award certainly poses delicate questions for domestic constitutional law and for the separation of powers in any constitutional order, and for foreign relations law research in general.

68 For a discussion of the relationship between domestic courts and arbitral tribunals from the perspective of transformative constitutionalism in Latin America, see René Urueña, 'Después de la fragmentación: ICCAL, derechos humanos y arbitraje de inversiones', in Armin von Bogdandy et al. El constitucionalismo transformador en América Latina y el derecho económico internacional: De la tensión al diálogo (México: UNAM/MPIL, 2018), pp. 59-85.

69 See generally Leon Trakman, 'Domestic Courts Declining to Recognize and Enforce Foreign Arbitral Awards: A Comparative Reflection' (2018) 6 The Chinese Joumal of Comparative Law 174. On the annulment of arbitral awards by third countries, see Felix Boor, 'Die Aufhebung der Yukos-Schiedssprüche des Permanent Court of Arbitration vor dem Bezirksgericht in Den Haag - nur der Anfang einer langen Vollstreckungsodyssee?' (2018) 54 Archiv des Völkerrechts 297.

$7 \circ$ Chevron Corporation and Texaco Corporation v. The Republic of Ecuador, Case No. 2009-23, Second Partial Award on Track II, 30 August 2018. On this lengthy litigation, see generally Hannah Franzki and Johann Horst, 'On the Critical Potential of Law - and its Limits: Double Fragmentation of Law in Chevron vs. Ecuador', in Kerstin Blome et al. (eds.), Contested Regime Collisions: Norm Fragmentation in World Society (New York: Cambridge University Press, 2016), pp. 347-70. 
2 Sovereignty in the Guise of Property: Hybrid Foreign Relations and State-Owned Enterprises

If international investment law is being rebalanced towards sovereignty, then sovereignty is at the same time being transformed by a symbiosis with property: state-owned enterprises, hybrid public-private entities or partly privatized corporations are increasingly internationalizing their activities. ${ }^{71}$ In this regard, the maybe most significant transformation of foreign relations is the globalization of Chinese state-owned enterprises and the rise of foreign investment by sovereign wealth funds..$^{72}$ In a parallel development, sovereignty appears in the guises of property in large-scale land acquisition by public investors in Africa and elsewhere, which potentially disassembles territorial sovereignty of host states. ${ }^{73}$ In all these instances, foreign relations acquire a hybrid nature - private in form but public in substance.

To analytically capture this hybridization, foreign relations law research needs a more complex account of the corporation than liberal legalism ordinarily gives. If "corporate governance has become a tool to advance China's strategic goals, ${ }^{74}$ as the Trump administration laments, then foreign relations lawyers need to understand non-liberal conceptions of the corporation in China and other capital exporting countries. ${ }^{75}$ Huawei, for instance, is

${ }^{71}$ Michael J. Strauss, Hostile Business and the Sovereign State: Privatized Governance, State Security and International Law (Milton: Routledge, 2019). To peripheral countries, this is not news, if one remembers that most colonial trading companies were public-private ventures, and were treated as such by the courts, McLachlan, Foreign Relations Law, 49, citing the case Nabob of Arcot v. East India Company [1793] EngR 1368, (1792-1793) 2 Ves Jun 56, (1793) 30 ER 521 (Company held not to be a private person, and its agreement with a foreign ruler 'the same, as if it was a treaty between two sovereigns').

72 Li-Wen Lin and Curtis J. Milhaupt, 'We Are the (National) Champions: Understanding the Mechanisms of State Capitalism in China' (2013) 65 Stanford Law Review 697; Gregory Shaffer and Henry Gao, ‘A New Chinese Economic Law Order?', Univ. of California Legal Studies Research Paper Series (No. 2019-21), April 11, 2019, https://papers.ssrn.com/sol3/papers .cfm?abstract_id=3370452; Ronald Gilson and Curtis J. Milhaupt, 'Sovereign Wealth Funds and Corporate Governance: A Minimalist Response to the New Mercantilism' (2008) 60 Stanford Law Review 1345.

73 Lorenzo Cotula et al., Land Grab or Development Opportunity? Agricultural Investment and International Land Deals in Africa (London: IIED,FAO and IFAD, 2009); Saskia Sassen, 'Land Grabs Today: Feeding the Disassembling of National Territory' (2013) 10 Globalizations 25; Jochen von Bernstorff, "Who Is Entitled to Cultivate the Land? Sovereignty, Land Resources and Foreign Investments in Agriculture in International Law', in Francesca Romanin Jacu, Angelica Bonfanti and Francesco Seatzu (eds.), Natural Resources Grabbing : An International Law Perspective (Leiden: Brill Nijhoff, 2016), pp. 55-74.

74 White House Office of Trade and Manufacturing Policy, How China's Economic Aggression Threatens the Technologies and Intellectual Property of the United States and the World, 1, 11.

75 For a comparison of liberal and non-liberal conceptions of the corporation see Teemu Ruskola, 'What Is a Corporation?: Liberal, Confucian, and Socialist Theories of 
formally not a public enterprise but employee-owned; but Chinese law may have other ways of establishing state control. ${ }^{76}$ Comparing these different theoretical and legal conceptions of the corporation will be a first important avenue of research for comparative foreign relations lawyers.

A second set of questions pertains to the constitutional rights of foreign stateowned corporations. For instance, the German Federal Constitutional Court held in its 2016 decision on the phase-out of nuclear energy that Vattenfall, a Swedish state-owned enterprise, enjoyed constitutional protection of property in Germany. ${ }^{77}$ Although the court was careful to limit its reasoning to 'exceptional cases' of enterprises owned by EU member states, there still remain many open questions for foreign relations lawyers in this regard not least because Vattenfall has initiated parallel arbitration procedures and because the European Court of Human Rights recognizes property rights of state-owned enterprises regardless of EU membership. ${ }^{7^{8}}$

While granting constitutional rights to foreign state-owned enterprises limits the space for regulation in this regard, another legal institution raises even farther-reaching issues: namely, sovereign immunity and its application to state-owned enterprises in foreign courts. While the German Constitutional Court adopts a restrictive stance on acta iure gestionis, ${ }^{79}$ Chinese state-owned enterprises seem to have successfully invoked sovereign immunity in US federal courts, prompting proposals for reform. ${ }^{80}$ If granted, immunity not only poses problems from a rule of law perspective but also limits the reach of democratic economic regulation. ${ }^{81}$

Enterprise Organization (and State, Family, and Personhood)' (2014) 37 Seattle Univ. Law Review, 639 .

76 Demetri Sevastopulo, 'Huawei Pulls back Curtain on Ownership Details', Financial Times, February 27, 2014, www.ft.com/content/46gbdezo-geaf-11e3-8663-ool4ffeab7de. See also White House Office of Trade and Manufacturing Policy, How China's Economic Aggression Threatens the Technologies and Intellectual Property of the United States and the World, $18 \mathrm{f}$.

77 Federal Constitutional Court, BVerfGE 143, 246

$7^{8}$ Islamic Republic of Iran Shipping Lines v. Turkey (Appl. No.40998/98), Judgment of 13 December 2007. For a general discussion of the issues, see Jochen Rauber, Zur Grundrechtsberechtigung fremdstaatlich beherrschter juristischer Personen: Art. 19 III GG unter dem Einfluss von EMRK, EU-GRCh und allgemeinem Völkerrecht (Tübingen: Mohr Siebeck, 2019).

79 BVerfGE 16, 27 - Iranische Botschaft; BVerfGE 117, 141 - Immunität Argentiniens. For a discussion, see Rauber, Zur Grundrechtsberechtigung, pp. 33 f.

8o US-China Economic and Security Review Commission, 2017 Report to Congress, November 2017, www.uscc.gov/sites/default/files/annual_reports/2017_Annual_Report_to_C ongress.pdf, p. 4, 29.

81 See generally McLachlan, Foreign Relations Law, Ch. 12. 


\section{Limiting or Legitimizing Private Quasi-Sovereignty: Business and Human Rights and Is Alternatives}

If Northern efforts to internationalize corporate rights in investment law have succeeded, Southern attempts at internationalizing corporate obligations have failed so far: early initiatives at UN level, launched by Allende's Chile and its allies, led to the establishment of a UN Commission on Transnational Corporations in 1975 and to a soft-law code of conduct, but not to a binding legal instrument. ${ }^{82}$ Regulation remained mostly at national level and thus vulnerable to bilateral pressures, collective action problems and regulatory arbitrage in a globalized political economy. This situation has not changed thus far with the renewed push for internationalization under the rubric of 'business and human rights', although developing countries are spearheading negotiations for a binding treaty on business and human rights, supported by China and opposed by most Western liberal democracies. ${ }^{83}$

The legal focus thus remains on domestic law, and thus on the foreign relations law of investor home states and host states. The current debate centers on the role of home states in the extraterritorial protection of human rights against corporate misconduct in host states. ${ }^{84}$ Since the US Supreme Court has all but closed the door to the extraterritorial application of the Alien Tort Claims Act, the focus has shifted to domestic courts in Europe and to legislative projects, enacted for instance in California and in France and tabled in Germany in February 2019. ${ }^{85}$

82 Tagi Sagafi-nejad and John H. Dunning, The UN and Transnational Corporations: From Code of Conduct to Global Compact (Bloomington: Indiana University Press, 2008); Jennifer Bair, 'Corporations at the United Nations: Echoes of the New International Economic Order?' (2015) 6 Humanity 159; Pahuja and Saunders, 'Rival Worlds and the place of the Corporation in International Law'.

83 Surya Deva and David Bilchitz (eds.), Building a Treaty on Business and Human Rights: Context and Contours (Cambridge: Cambridge University Press, 2017).

84 Jennifer Zerk, 'Extraterritorial Jurisdiction: Lessons for the Business and Human Rights Sphere from Six Regulatory Areas', Harvard Corporate Social Responsibility Working Paper No. 59 (June 2010), www.hks.harvard.edu/sites/default/files/centers/mrcbg/programs/cri/files/ workingpaper_59_zerk.pdf; Jochen von Bernstorff, 'Extraterritoriale menschenrechtliche Staatenpflichten und Corporate Social Responsibility' (2011) 49 Archiv des Völkerrechts 34; Thilo Marauhn, 'Sicherung grund- und menschenrechtlicher Standards gegenüber neuen Gefährdungen durch private und ausländische Akteure' (2015) 74 Veröffentlichungen der Vereinigung Deutscher Staatsrechtslehrer 373.

85 Dalia Palombo, "The Duty of Care of the Parent Company: A Comparison between French Law, UK Precedents and the Swiss Proposals' (2019) 4 Business and Human Rights Journal 265; Saskia Wilks and Johannes Blankenbach, 'Will Germany Become a Leader in the Drive for Corporate Due Diligence on Human Rights?', February 20, 2019, www.business-human rights.org/en/will-germany-become-a-leader-in-the-drive-for-corporate-due-diligence-on-hum an-rights. 
A peripheral perspective, however, raises further questions. Firstly, from this perspective, the focus on extraterritorial home state obligations and regulations is ambivalent: it not only subjects host states to standards defined and applied elsewhere but also implies that host state legal systems are incapable, or unwilling, to dispense justice. While this may be true in some cases, it cannot be assumed for all jurisdictions, especially the many constitutional democracies with independent courts in the Global South. Indeed, a peripheral perspective might reverse the focus and ask to what extent host state regulation and adjudication can and should be extended extraterritorially to govern global value chains and transnational corporate conglomerates. Taking host state law seriously brings distinct regulatory approaches to the table - such as horizontal effect of fundamental rights. The idea of horizontal effect is a hallmark of transformative constitutionalism in the Global South and is used by activists and social movements against corporate abuses of powers. ${ }^{86}$ In substance, this approach redeploys the vocabulary and legal techniques developed to restrain public authority to tame private power.

The consequences of this move for separation of powers, democracy and foreign relations remain to be fully understood. One consequence of applying fundamental rights to transnational corporations is that courts effectively become extraterritorial regulators and tend to be empowered vis-à-vis the other branches. This is potentially a problem from a liberal foreign relations law perspective; it may be less problematic for a transformative constitutionalism that prizes activist courts and an understanding of separation of powers not limited to checks and balances but also encompassing pushes and pulls. Beyond this, there are issues of separation between public and private power. Some see horizontal effect as a basis for corporate commitments to human rights, a desirable ‘self-constitutionalization' of transnational enterprises and a basis for a societal constitutionalism beyond the state. ${ }^{8}$ Others fear that a rights-based societal constitutionalism will not restrain but rather legitimize private power. ${ }^{88}$ Likening a corporation to a state for purposes of

86 David Bilchitz, 'Constitutionalism, the Global South, and Economic Justice', in Daniel Bonilla Maldonado (ed.), Constitutionalism of the Global South: The Activist Tribunals of India, South Africa, and Colombia (Cambridge: Cambridge University Press, 2013), pp. 41-94; Hailbronner, 'Transformative Constitutionalism: Not Only in the Global South'.

87 Gunther Teubner, 'Self-Constitutionalizing TNCs?: On the Linkage of 'Private' and 'Public' Corporate Codes of Conduct' (2011) 18 Indiana Journal of Global Legal Studies 17; Gunther Teubner, Constitutional Fragments: Societal Constitutionalism and Globalization (Oxford: Oxford University Press, 2012).

88 Christian Scheper, "From Naming and Shaming to Knowing and Showing”: Human Rights and the Power of Corporate Practice' (2015) 19 International Journal of Human Rights 737. For a different notion of societal constitutionalism, see Gavin Anderson, 'Societal 
human rights obligations might confirm, rather than restrain, their quasisovereign status. Domestic courts are faced with these controversies when pondering the legal value of corporate human rights standards in litigation.

In light of these doubts, a third and final question pertains to alternatives to the business and human rights frame from a peripheral foreign relations law perspective. Again, Allende's speech offers such an alternative perspective: his concerns and proposals were not formulated in the liberal language of rights but in the register of democracy. While ideas about economic democracy and workers co-determination have lost traction in a globalized economy dominated by (neo)liberal thinking, it may be worth reflecting on how the vocabulary of collective self-determination may be used creatively within the contemporary globalized economy. For instance, resurgent interest in inequality has led to greater space for alternative visions of corporate governance that go beyond 'shareholder democracy' and 'corporate citizenship' on the one hand, and nationalization and state ownership on the other. Such proposals are based on the premise that the corporation, conceived as a political entity, allows similar collective participation rights than the political sphere and that these rights do not depend on ownership. Rather, they allow for inclusion of workers and other stakeholders affected by corporate activities. ${ }^{89}$ In these schemes, peripheral countries would benefit from the inclusion in corporate decision-making by virtue of their labor and affected stakeholders. This might alter the current North/South dynamics of capital exploitation by promoting economic democracy in developing countries through formally private initiatives that potentially bypass current barriers to more democratic economic reforms in highly unequal societies with unresponsive political regimes.

\section{CONCLUSION}

Peripheral legal ideas are not exclusive to an essentialized 'Global South' but are present in legal history, heterodox thinking and contemporary legal transformations across the North-South divide. In foreign relations law, peripheral

Constitutionalism, Social Movements, and Constitutionalism from Below' (2013) 20 Indiana Journal of Global Legal Studies 881. On self-regulation generally, see also A. Claire Cutler, Private Power and Global Authority: Transnational Merchant Law in the Global Political Economy (Cambridge: Cambridge University Press, 2003).

89 Isabelle Ferreras, Firms as Political Entities: Saving Democracy through Economic Bicameralism (Cambridge: Cambridge University Press, 2017); David Ciepley, 'Beyond Public and Private: Toward a Political Theory of the Corporation' (2013) 107 American Political Science Review 139. On a Chinese experiment in this regard, see Karita Kan, 'A Weapon of the Weak? Shareholding, Property Rights and Villager Empowerment in China' (2019) 237 The China Quarterly 131. 
ideas are often located at the margins of, or outside, a field of study defined by a liberal perspective from the center. A peripheral perspective brings these questions into sharper focus, and it offers different answers contingent on differing geopolitical positions and epistemic foundations. This raises the question of whether there are any lessons to be learned from experiences of the periphery for our normative evaluation of present-day challenges across the North-South divide.

That question must be denied if one assumes a view of history and time that follows a liberal narrative of progress and a singular conception of modernity: The West is ahead, everyone else is catching up. If one accepts, instead, the idea of multiple modernities and nonlinear historical evolution, one may see the history of Southern countries as an inspiration - and as a warning. ${ }^{\circ}$ One ironic aspect of the recent backlash against internationalism are the curious echoes of anticolonial nationalism in the language of populist nationalism for instance, in Brexit proponents' appeals to national liberation and to individual sacrifice as necessary for achieving this goal. ${ }^{91}$ These echoes are reason enough to recall postcolonial critiques of 'national liberation', which left unresolved the question of who would govern the nation once liberated, and who would do the sacrificing. Franz Fanon warned of the pitfalls of 'national consciousness', seeing within the liberation movements a group of bourgeois leaders who 'mobilize the people with slogans of independence, and for the rest leave it to future events' and are committed only to a 'mission [that] has nothing to do with transforming the nation; it consists, prosaically, of being the transmission line between the nation and capitalism'. ${ }^{2}$

9० Hoffmann, 'Knowledge Production in Comparative Constitutional Law'; Peter Wagner, Modernity: Understanding the Present (Cambridge: Polity, 2012).

$9^{1}$ Kojo Koram, 'Britain's Blindness: How did “national liberation” become a rallying cry in what was once the world's largest empire?', Dissent Magazine, February 6, 2019, www.dissentmagazine.org /online_articles/britains-brexit-blindness.

92 Fanon, The Wretched of the Earth, p. 100. 